\title{
Feeling 'Brexit': Nationalism and the Affective Politics of Movement
}

\section{Angharad Closs Stephens (Department of Geography, Swansea University)}

\section{Abstract}

'Brexit' reveals the necessity of understanding the role of affect in political life, in particular in constituting ideas about nationality and in animating the politics of populism. This article discusses what 'Brexit' felt like in the year following the UK vote-held on 23 June 2016-to leave the European Union through a performance called 'The Populars' created and performed in 2017 by Volcano Theatre, in Swansea (Abertawe). In this paper, I discuss feelings of shame, hostility and resentment and situate them in relation to the crises of British multiculturalism and rise of populism, before turning to how such feelings were addressed in this performance through movement and dance. The article addresses three specific contributions that engaging affect does in the context of 'Brexit': first, it forms an invitation to address heightened political feelings; second, it suggests an alternative approach to the politics of knowledge to that enabled by a focus on voter interests or identities; third, it opens up other ways of understanding being in common. Overall, I make the case for how an affective approach to the politics of movement suggests ways of thinking and acting politically that defy the closures of nationalist populism.

\section{Keywords}

Affect. M ovement. Brexit. Nation. Shame. 


\section{Acknowledgments}

Thank you to Catherine Bennett and Paul Davies for inviting me to think about politics through movement. Thanks also to the cast, to Claudine Conway and Kay Nenyer at Volcano Theatre and Vic Boobyer for permission to use the photographs. Versions of this paper have been presented at the Royal Geographical Society conference and $11^{\text {th }}$ Pan-European Conference on International Relations (September 2017), Sussex University Geography Department (M ay 2018), École des Hautes Études en Science Sociales, Paris (June 2018) and the Geography Department, University of M elbourne (February 2019). Thank you to those who invited me, especially David Bissell, Eva Illouz, Ben Rogaly, Shanti Sumartojo, to the warm audiences at each event and to M arcus Doel and Martin Coward for comments on an earlier draft.

\section{Figure captions}

1. Volcano Theatre, High Street, Swansea (Abertawe). Photo courtesy of Volcano Theatre.

2. 'The Populars', April 2017. Photo courtesy of Volcano Theatre.

3. 'The Populars', April 2017. From left to right: Elin Phillips, Rick Yale, Neal McWilliams, Roanna Lewis. Photo courtesy of Volcano Theatre.

4. 'The Populars', April 2017. Photo courtesy of Volcano Theatre. 


\section{Feeling 'Brexit'}

There is no shortage of opinion on what the Referendum held on 23 June 2016 and the UK's decision to leave the European Union represents: evidence of the enduring force of nationalist sentiment and imperial racism (Flemmen and Savage, 2017); of the declining health and living standards brought about by cuts to public services since 2010 (Dorling, 2016); or testament to the enduring legacies of the British Empire and how it shapes understandings of British national identity in the present (Bhambra, 2017; O'Toole, 2018). These are some of the most valuable explanations and yet, it is still not clear what kind of a thing 'Brexit' is (Anderson and Wilson, 2017) and what might yet unfold from it. What is clearer is how this political moment has been felt- -as an intensification in racism, Islamaphobia, and identity politics — and with those who voted to 'remain', myself included (Closs Stephens, 2016b) reporting that they felt great sadness and shame at this event.

In this article, I follow Sara Ahmed's invitation to 'feel our way' into how emotions work to shape individual and collective bodies, through racial and gendered discourses of nationhood (2004). Drawing on debates around affect in the humanities and social sciences, understood as an engagement with 'forces of encounter' that draw bodies together and apart (Seigworth and Gregg, 2010: 2), I argue that attending to affect can shift our understanding and engagement with the politics of intensified nationalism at work in 'Brexit'. Given the ways in which opinion polls based on political science's ideas about rational subjects acting on the basis of self-interest were unable to predict this vote (where $51.9 \%$ voted 'leave' and $48.1 \%$ voted 'remain', and 33,551,983 out of a total electorate of 
46,500,001 voted, BBC EU Referendum Results, 2016), I argue that we need other ways into understanding the politics of this event. Engaging affect invites us to address the heightened political emotions that played out in people's homes as well as on the street; it also proposes other ways of understanding the politics of being together with others.

I develop the article through a study of a theatre performance called 'The Populars', created by Volcano Theatre company, and performed in April 2017 at Volcano's temporary headquarters in a disused supermarket building in Swansea (in Welsh, Abertawe). 'The Populars' was directed by Paul Davies (co-founder of the company) with movement director Catherine Bennett. It presents an interesting case study for me because the Director wanted to address 'Brexit' through questions of feeling, and (as Davies confirms in a quote I return to) 'family, lovers, quite human things really, rather than policy or GDP' (Interview with Davies, 2017). Furthermore, they planned to address those 'Brexit' feelings by way of movement and dance. On hearing news of this impending play, and feeling keen to make sense of the unsettling times with others, I asked if I could sit in on the rehearsals. The company generously invited me to follow the production from the first rehearsal to the first performance - from February to April 2017. This article presents the conceptual work that emerged for me from watching and learning with the cast.

'The Populars' was built around fragments of text-including monologues, dialogues, rows, stories, quizzes and anecdotes-many of which were produced collectively and improvised. Importantly, there was no central argument or moral claim delivered in the performance. The article builds on interviews I carried out with the director and movement director, on fieldnotes from watching rehearsals, and questionnaires handed out to members of the 
public after selected performances as well as to Swansea University students who came to see the performace with me as part of their 'Political Geographies' course. It is beyond the scope of this article to engage with debates from theatre and performance studies about the specific form of theatre presented here, and the histories of experimental theatre. However, I draw on theatre geographies, especially arguments about how the arts can disrupt the standard categories and viewpoints of the social sciences (Ingram, 2011; Manning, 2016; Pratt and Johnston, 2013; Raynor, 2017; Rogers, 2017). I also draw on geographies of dance and the study of moving bodies, for how they open up different accounts of politics (Bissell, 2016; McCormack, 2008, 2013; Noxolo, 2018). Dance, as a cultural practice, has formed an important provocation for geographers (M cCormack, 2008, 2013; Noxolo, 2018), as has the concept of affect (Anderson and Harrison, 2010; Anderson, 2014; Dawney, 2013). The interest in dance is often inspired by the desire to grasp movement, and the idea of a body in motion. These are also central concerns for politics, for they help us address the grounded work that must take place if people are to gather in time and space to mobilise for change (Martin, 1998: 3), or come together and 'act like citizens' (Butler, 2015). Rather than think of politics as what affects otherwise still bodies, working with affect enables us to think the political through the presumption of 'bodies already in motion' (Martin, 1998: 3).

The article contributes to the growing literature on affect, emotion and the politics of nationality (Ahmed, 2004; Crang and Tolia-Kelly, 2010; Dittmer and Waterton, 2017; Edensor and Sumartojo, 2018; Fortier, 2008; Jones and Merriman, 2016; Militiz and Schurr, 2016): firstly, as subjects explicitly addressed in the themes of this play and secondly, as 
involving implications for the politics of knowledge- - - a core issue for this journal (Hawkins et al., 2015: 216). In this, I follow Eve Sedgwick's seminal writings on affect, as both an engagement with the emotional and the tactile as well as an invitation to open other approaches to the question of knowledge. For example, Sedgwick asks us what might critical theory do beyond rushing to expose a 'residual form of essentialism' (2003: 8), 'unconscious drives' (2003: 8) or 'oppressive historical forces' (2003: 8)? These are all tempting approaches when we seek explanations of 'Brexit' and other examples of 'the return of nationalism', but they are also insufficient. This is because critical approaches that rely on exposing identity politics or revealing enduring historical forces at work risk being too quick to declare that we already understand what is going on in this event. In contrast, I claim that the turn to affect invites us to think again about some of the core political ideas and figurations expressed in 'Brexit', namely the idea of 'the people' presumed by a sovereign politics (De Genova, 2018), as well as the categories of identities, nations, populations and representation - ideas that have become especially toxic as part of the politics of populism (Ahluwalia and Miller, 2018; M ouffe, 2018) but which are neverthelesss no more than a few centuries old (Appadurai, 2005: 49). It allows us to consider these political categories in relation to a statist understanding of politics and to uncover other kinds of political mobilisation already at work around us.

The first section of the article begins with a discussion of 'shame', and how cries of shame emerged in this context alongside the crises of multiculturalism (Lentin and Titley, 2011; Shilliam, 2016). The second section engages the increasingly prevalent figure of 'the people' from the perspective of this theatre's temporary home on High Street, Swansea, and the South Wales valleys more generally—a relatively poor region of Europe, which voted to 
'leave'. The third section discusses selected moments from the play and how feelings of shame, anger, resentment as well as the idea of 'the people' were gently and playfully set in motion. The fourth section develops some moments from the play to unpack how affect and movement recast our understandings of politics. I do so drawing largely on Erin Manning's The Minor Gesture (2016), in which she posits movement as 'capable of opening experience to new registers and creating new modes of existence' (2016: X). Working with Manning's contributions in that book, I contend that thinking with movement unsettles identity politics, because it carries the potential of transforming the very idea of 'the people'.

\section{Shame, resentment and the nation}

In the aftermath of the 'Brexit' vote, the prominent psychotherapist Susie Orbach spoke about how this was all people wanted to talk about in her therapy room. Patients shared feelings of shock, fear, dismay, shame, anger, alienation, and of 'mourning what one didn't realise one quite had' (Orbach, 2016). These feelings were not universally shared: they belonged mostly to the middle class, well-educated, cosmopolitan and urban. For example, the novelist Zadie Smith describes reading essays by 'Londoners speaking proudly of their multicultural, outward-looking city, so different from these narrow xenophobic places up north': she reflects on the problematic assumptions underlying these feelings of shame and regret: 
'What have they done?' we said to each other, sometimes meaning the leaders, who we felt must have known what they were doing, and sometimes meaning the people, who, we implied, didn't (Smith, 2016).

Smith goes on to castigate a 'Londoncentric solipsism' and conclude that a useful consequence of 'Brexit' is to 'openly reveal a deep fracture in British society that has been thirty years in the making' (2016). The idea that it was only middle class urbanites that felt ashamed at the results of the vote became a compelling narrative, and was reworked by the journalist David Goodhart to argue that the 'remain' vote belonged to people from 'nowhere', whilst people from 'somewhere' voted to leave (2017). This simplistic geography was powerful enough to be adopted by the British Prime Minister Theresa May in her speech to the Conservative party conference on 5 October 2016 (May, 2016; for a critique, see Rao, 2016). In this formulation, the myriad feelings, subjectivities and histories at work in the account of shame sketched by Zadie Smith are funnelled into a geography of 'us' and 'them', a geography that was also built into the blunt tool of a referendum.

Zadie Smith's essay suggests that feelings of shame have a moralising tone. In this case they mapped broadly onto a distinction between 'London' and 'the North', the city and the countryside, and the educated and the uneducated, all of which, on closer inspection of the the vote, failed as convincing explanations. As Danny Dorling makes clear, of those who voted Leave, $59 \%$ were 'middle class' (A, B, or C1 social groups) and $41 \%$ were 'working class' ( $D$ and E social groups - categories derived from the British National Readership Survey) (Dorling, 2016). The proportion of leave voters in the lowest two social classes was 
just $24.9 \%$. This meant that 'leave voters among the middle class were crucial to the final result' (Dorling, 2016, my emphasis). Yet despite the statistics, 'poor whites' were often blamed for the outcome. As Bhambra (2017) and Younge (2016) point out, this category is a constructed one. Whilst race remains central to the production of subject positions in a capitalist economy (Hosang and Lowndes, 2019: 9), the 'white working class' has been constituted as a problem throughout colonial histories (Stoler, 2010: xv). As Bhambra argues, the debate over whether 'Brexit' should be understood in relation to identity politics or in the context of socio-economic inequality therefore misses the ways in which it must also be read in relation to the histories of the British Empire (2017). For example, collective affects of 'shame' are powerful and comforting because of the ways they in part rely on ideas about how some people are more progressive, developed and enlightened than others (M assey, 2005) confirming colonialism's 'affective afterlives' (Pedwell, 2013). The feelings of 'shame' that travelled through this vote achieved their affective resonance partly because of the ways they reverberated with colonial figurations of 'the other'-imagined as both within and beyond the nation.

Along with fear, love and pride, shame has attracted the interest of those seeking a critical understanding of the intersecting logics of nationality, multiculturalism, coloniality, and racism (Ahmed, 2004, 2010; Fortier, 2005, 2008; Hage 2012; Povinelli, 2002). Examining how feelings of shame inform ideas about Britishness in an earlier context- - that of the public mood that greeted the publication of the Parekh report on the Future of Multi-Ethnic Britain in 2000-Fortier interrogates what seemed then to be a general political consensus around 'multicultural tolerance'. In 2000, former Conservative leader William Hague claimed his 
'pride' in the fact that Britain was 'a nation of immigrants' —a claim that is hard to imagine a British political leader making in the context of 'Brexit'. Fortier documents the shift in public debate during the 1990s towards a British version of multiculturalism, and how, as part of that, shame was 'evoked, rejected and projected onto particular subjects' in the formation of a national identity of 'us' and 'them' (2005: 561). For example: one of the passages of the Parekh report that received attention was one that rejected 'Englishness' as a label for the new British multicultural nation, because of the historical connections between English identity, white supremacy and imperialism (Fortier, 2005: 563-4). This prompted cries that Britain should not be 'ashamed of its history'. Fortier shows how shame was repelled as something 'we' did not want to feel. These histories, of the protracted afterlives of Empire are deeply interwoven in 'Brexit', evident in the persistence of racialised dreams of white superiority as well as the re-emergence of the 'problem' of Ireland (Toole, 2018; Younge, 2016).

The intersection between feelings of shame, nationality and coloniality are also addressed by Elizabeth Povinelli in relation to Australia's public debates and sentiments formed around the rights of indigenous communities. She offers a critical reading of the 1992 Australian High Court ruling on the native title rights of indigenous Australians and how this became part of a newly reconstituted multicultural Australian nation. In doing so, she shows how racial and cultural intolerance were projected as things belonging to the past. In her critical reading of how shame, multiculturalism and nationality overlap in this context, she shows that the state (via the court) relies on both an abstract language of law, citizenship, rationality and rights and an emotional language of love and shame in its discourses of 
governance (1998: 580). In a not dissimilar critique of multiculturalism to that offered by Fortier, she situates it within a broader ideology of 'late liberalism', and accuses it of being unable to acknowledge differences that do not 'fit' the multicultural nation's ideal image of itself. Both Fortier and Povinelli's works are useful in considering how shame has operated in, through and alongside liberal multiculturalism. However, that context, of a presumptive liberal multiculturalism now also finds itself in crisis (Lentin and Titley, 2011), in Europe at least. How do we understand this shift in narratives of patriotism, discourses of governance and their relationship to the liberal state in ways that refuse to claim that we already know the forces at work?

Ideas about shame interconnect with ideas about the nation, Europe, modernity, civilization and multiculturalism in very different ways in these examples, leading to some familiar closures—such as the imaginative geographies of us/them—but also to political openings. For example, shame has been used creatively and inventively, by LGBTQ activists and HIV/AIDS activists to renarrate the nation (Probyn, 2000). Shame, for Sedgwick, has radical potential (2003). Drawing on the work of Silvan Tomkins, she argues that shame marks us as engaged with and interested in the world, for it 'derives from and aims towards sociability' (Sedgwick, 2003: 37). In Probyn's treatment of shame, which reflects on the histories of white feminism, she says that shame can present something more interesting than empathy - where we pretend there are lines of connection. In contrast, shame invites us to be 'interested in those we see as our enemy' and where the impossibility of sharing commonality may nevertheless produce 'localized action' (2005: 106). An affective approach to shame therefore potentially displaces the focus on it as something emerging from an 
unconscious drive and/or belonging to a bounded subject: it allows us to consider shame, alongside other affects, as a 'transmission of force or intensity across bodies, and not only human bodies' (Clough, 2010: 224). Such affects are shifting, plural, mobile. Operating between consciousness and unconsciousness, they are open to change and lively formulations.

\section{A Perverse Politics?}

One of the news stories that perplexed the cosmopolitan liberal broadsheets in the aftermath of this vote was how people living in the South Wales Valleys could vote to leave the EU when they had benefitted so much financialy from European subsidies (Cadwalladr, 2016). This region lost all its major industries under Thatcherism, is one of the poorest in the European Union and has, for that reason, received significant funding from EU structural funds (Welsh Government, 2018a). Health indices show that women who live in Blaenau Gwent can expect to have a 'healthy life' expectancy of 59.3 years, in comparison with 70.7 years in nearby M onmouthsire (M easuring Inequalities, 2016). Yet Ebbw Vale (a town in the Blaenau Gwent constituency) was singled out in this Guardian article as a 'town showered with cash'. This constituency voted $62 \%$ to leave, $38 \%$ to remain, on a turnout of $68.1 \%$ (BBC News, EU referendum results). There is much to unpack in the question of how some places get singled out as intensely interesting (or responsible) at times of national crisis. But the key point I want to focus on here is how this issue of people apparently voting against their own interests brought political science's categories of 'group identities' and 'voter interests' into view. It invited us to imagine a coherent class or identity that had failed to 
grasp how much it has benefitted from 'Europe'. It also postulates another, more learned group, that is well educated enough to know how important it is to remain part of 'Europe'. This framing reproduces colonial narratives about some people being more educated and enlightened than others, which operated alongside an already highly charged atmosphere of everyday racism. It also ensured that 'Brexit' had transnational resonances, for a similar question—of how people could vote against their own interests-is being asked in the US context, notably in Kathleen Cramer's The Politics of Resentment (2016) and Arlie Russell Hochschild's Strangers in Their Own Land (2016).

In Cramer and Hochschild's books, the authors (self-confessed liberal-minded democrats) go and meet people in other parts of the US (in Wisconsin and Louisiana respectively) in order to understand increasing resentment and divisiveness in US politics. In their different ways, both authors try to move beyond 'shame' towards a genuine engagement. Both present rich ethnographic work. Indeed, the everyday views presented in Cramer's study are so moving that they seem as if they could have been spoken in Swansea (or in Stoke on Trent, or Sunderland): people speak of the pain of watching other cities able to offer much more to their children; of feeling that voting never makes a difference; and of the significant difference it makes when one petrol station, shop or bank closes. But this is also partly why Cramer's explanation of her participants' feelings as something that results from a 'rural consciousness' does not convince: because these views are heard in cities too. The problem lies with how identity, rurality and the city are seen as categories that fit into the political unit of the state, leaving the state not only unqestioned but presumed as a unifying force for good (Ray, 2017). This has the effect of leaving questions of colonialism, white supremacy 
and racism either outside of the frame (Smith, 2016) or neutralised as examples of 'inequality' (Lentin, 2018: 45).

In her review of Hochschild's book, Ray suggests that it might not seem to the people of Louisiana, which ranks 49/50 for human development (Ray, 2017: 131) as if the state is on their side. Yet what is particularly useful in Ray's response is how she queries the representation of a vote for populist leaders and policies as a 'perverse politics' (see Orloff, Ray, Savcı, 2016). What kind of political protest and agitation is at work in such a vote, and how does the characterisation of it as perverse obfuscate these political issues? Leaving aside for now the point that 'Brexit' can be attributed to a longstanding tension in the British Conservative party on the question of Europe, the moral reproach, touched upon in the last section, avoids the work of acknowledging Europe's deep political crises (De Genova and Tazzioli, 2016; Varoufakis, 2017). For populist revolts also form a response to a crisis of political institutions, of legitimacy and representation (Balibar, 2017). In my interview with 'The Populars' director Paul Davies, we talked about the blue signs with a EU flag that are dotted throughout Swansea and the accompanying Welsh valleys, and which identify building projects made possible by EU structural funds. He said:

prior to [the vote], I'd been up the Valleys, photographing where my family is from... You just got the feeling that...it [Europe] just doesn't mean anything... yes you see the wee little flag on the side of a road but we are miles away from all that... So I guess that's a lived feeling... 
As Davies indicates, there are 'lived feelings', political inequalities and injustices that cannot be appeased by great big funding projects. What happens, then, if we refuse to translate the collective anger, sadness and sense of injustice felt by so many into straightforward, recognisable identity positions? It might mean refusing to meet the present moment with answers that are already available and ask instead how we might engage these times in ways that refuse the tired framings?

\section{'The Populars'}

The High Street in Swansea connects the central train station with its historic castle. Her Majesty's Land Registry show the price paid for a flat here in May 2015 was $f 71,000$, another was bought in July 2017 for $£ 60,000$. This is in comparison to the average cost of a flat or maisonette in the UK which in November 2018 was $£ 202.663$ (Land Registry, 2018). This street is emblematic of the brutal nature of global capitalism and looks very different to the pictures of what was once, in the early Twentieth Century, a buzzing street, with a tram, colourful shop awnings and advertising boards above shop windows. As several shops today stand empty or boarded up, with many buildings converted into student housing, it is evident that High Street has suffered from the growth of private cars, large out-of-town chain stores and the redistribution of wealth to other UK towns and cities. Nevertheless, on

this street today are markers of Swansea's ordinary cosmopolitanism: a world food supermarket with large Polish food section, a Turkish restaurant, an Italian café, several artist studios. Luckily, this street remains poor enough to be of little interest to the large 
chain stores and upmarket restaurants. As with the former industrial cities of Eastern Europe, whose abandoned shops are a sight for sore eyes for some, for others, they are aesthetically inspiring (Pusca, 2010). Indeed, High Street, Swansea, has made national headlines for the small but innovative initiatives at regeneration through the arts that decorate this street (West, 2016). These include painted empty shop fronts and artist designed shop awnings (largely funded by the 'From the Station to the Sea', Arts Council of Wales project). The 'affective urbanism' of this street (Anderson and Holden, 2008) and its everyday conviviality (Rogaly and Rishbeth, 2017) offers us a different starting point for thinking about 'Brexit'.

\section{Figure 1. Volcano Theatre, High Street, Swansea (Abertawe). Photo courtesy of Volcano Theatre.}

This street also forms a temporary home for Volcano Theatre company (Figure 1), where between 27 March and 8 April 2017, 'The Populars' was performed. Being new to this city and having moved here just before the 'Brexit' vote, I felt eager to make sense of the times with others. The 'patient experimentation' (Manning, 2016: 13) of the rehearsal process opened up a space that went beyond the invitation to identify with one side or another, and allowed the cast and broader crew to talk through what kind of a political crisis this was. As Paul Davies told me in an interview, carried out when the cast had just started rehearsing: 
I think it became apparent that within liberal arts constituencies in Wales and beyond, that there was a huge amount of concern as to the prospect of a Leave vote and then after the Leave vote there was a huge amount of concern, and agitation and groups being set up and outrage in terms of media and conferences but then nothing actually being presented in performance. [So I thought], if it was that important and that galvanizing, how come it doesn't generate anything actually creative? (Interview, Feb 2017)

'Brexit' formed a political event insofar as people departed from the scripts that they were expected to follow. But it was not accompanied by broader debate, demonstration, protest, or people gathering together in public-at least initially. Political affects of excitement, happiness and joy were hard to find.

'The Populars' began for Paul Davies with how people felt, but the aim was not to give voice to public moods and views that were already vocal. For 'Brexit' had also unfurled in people's homes, among family and friends: a critical response needed to somehow address that. In our interview, Davies insisted the play was not about 'Brexit' and in casting, he had avoided mentioning it as such. This allowed him to engage 'Brexit' through another register-which given the intensity of the political atmosphere, was both a difficult and a necessary task:

When I did get four actors in a room for a kind of R\&D [Research and Development], around two months after the vote, it was apparent that it kind of, that it touched on all sorts of weird things like family, 
lovers, quite human things really, rather than policy or GDP. And then I thought oh there is something that connects back to dramatic realism here. Not that that interests me much. And I was looking at a book called Human Space by Otto Fredrich Bollnow (1963). Quite an old book now. I had these actors in a space and they had no idea what I was thinking about. And I was thinking about space, and proximity and I deliberately wanted four people who didn't know each other and put them apart-together, apart-together. It was only on the third day when I played The Clash's 'Safe European Home'... that they all went, oh right, this sounds like it's about... BREXIT!'

The performance was built from a series of structured improvisations and fragments of script, dance, music, and movement. There was no set design or special lighting: only some fancy dress costumes for selected routines. It was performed in promenade and the audience mainly stood around the space (though there was space for some to sit). We were invited to listen, attune and eventually join in the dancing. The cast of four actors, two men (Neal McWilliams and Rick Yale) and two women (Elin Phillips and Roanna Lewis), worked hard to establish a mood. As such, this was much more demanding on them than a play that presented different viewpoints to an audience of passive receptors. The atmosphere varied with different audiences on various nights but it was often fragile, as we were conscious that the invitation to move together could easily be rejected. 
To open the show, the audience moved from the front end of the 'shop' to the theatre space at the back of the building where the supermarket's deep freezers used to be housed, which is partially beneath street level. A temporary bar had been built front of house, which welcomed us from the street to this open, low-cost space. In the dimmly lit theatre, two of the actors could be seen dancing to Chet Baker's 'Alone Together'. Against this modest backdrop and jazz music, a mood was created. On entering the space, listening to the music and watching their bodies move to the rhythms, I was carried away from the demands of targets, rankings and outputs of the neoliberal university. The actors danced as if they were alone, but in entering, we became aware of ourselves sharing this intimate space together, on leave just for a short while from whatever else awaited us.

\section{Figure 2. 'The Populars', April 2017. Photo courtesy of Volcano Theatre.}

The music moved into pop and the lights went up: all four actors were present and began dancing energetically to the hit song, 'Jump Around' by House of Pain then later Fleetwood Mac's 'Everywhere' (a rejoinder to the citizens from somewhere or nowhere debate), as well as a string of 1980s and 1990s feel-good music including Madonna's 'Material Girl', Right Said Fred's 'I'm Too Sexy' and Pulp's 'Common People' (Figure 2). This was a 'happy to be alive' kind of dancing. It was dancing that was hard to watch without finding your toes tingling, eager to move. The two women jumped for the entire song as the two men gyrated on the floor. In my interview with the M ovement Director Catherine Bennett, held following the show's run, she felt it was important that none of the actors were trained dancers: they were strong but they did not make far-reaching movements look easy through years of 
repetitive practice. The actors were all young people (under 35), which felt significant given that $75 \%$ of those aged $18-24$ had voted to 'remain' (Yougov, 2016).

After the slow then fast tempo of the music and dancing, we arrived at the first of a series of improvised fragments. Elin Phillips began by asking audience members about 'being cool'. She took a microphone and gently asked an audience member: 'are you cool?' In the performance I went to see with my undergraduate students, this question was met with quiet laughter and nervousness: who would say something first? What was the right thing to say? One pitched in and said: 'Yes, I'm cool!' Everyone laughed. We eased up. The actors laughed with us. In another fragment, the actors talked about the similarities and differences between European people, in a way that mimicked the world of 'alternative facts': 'Did you know that in Italy it's illegal to drink cappuccino after 11am?' 'Did you know that in France it's illegal to name your pet pig Napoleon?' 'Did you know that the Welsh word for 'speed up' is 'araf'?' Through their funny, made-up questions, which changed in each performance, we slowly had to leave behind representations of the 'serious views' of the people- . This was not an easy task in this political climate, for in the context of 'populist' politics and this most potent symbol of 'the will of the people' - a won referendum -- - 'the people', who were of course, not all of the people - appeared as both loud and difficult to challenge. But this performance refused to engage on this terrain. This was not about countering 'false facts' with truth. Rather than seek to return politics to the 'right' people, this performance went about setting the very idea of the people in motion (Figure 3). 
Figure 3. 'The Populars', April 2017. From left to right: Elin Phillips, Rick Yale, Neal McWilliams, Roanna Lewis. Photo courtesy of Volcano Theatre.

\section{Movement and Modes of Being With Others}

Erin Manning's The Minor Gesture develops a philosophy of movement which is principally concerned with how to foster modes of being with others. Indeed, she defines politics along these lines-as what 'awakens new modes of encounter and creates new forms of lifeliving' (2016: 8). In order to get there, she attends to the co-composition of bodies and worlds and the interplay of conscious and non-conscious movements. For example, rather than assume a philosophy of still life, from which bodies begin to move, she encourages us to think about bodies and the world as both in perpetual movement (see also Bennett, 2013). She draws on the work of dancers, choreographers and philosophers, as well as work on depression, and on living with autism-all, she is careful to say, very different life experiences. I turn here briefly to the chapter she develops in response to writers writing about living with autism, which include Ido Kedar, Tito Mukhopadhyay, DJ Savarese and Amelia Baggs. Mindful not to romanticise this condition, nor underplay the serious challenges of living with different forms of body disturbance in a world that is not planned around such needs, she uses this work to develop a discussion of the presumed split between body and world, endemic to a 'neurotypical' account of experience. The point is to learn from an account of perception that 'privileges the complexity of experience of category' (2016: 112). For example, drawing on Anna Corwin, who writes about her own experience of living with autism, Manning relays how the 'entry into an environment begins 
not with a perception of objects (chairs, tables) or of subjects (people) but with an edging into form, a tending of light and shadow and color' (2016: 112). Unlike a neurotypical account of experience, which might notice the objects and subjects first, this is an account that prioritises the affective and the 'active ecologies of experience' as they take shape (ibid). The decision made in 'The Populars' to eschew the theatrical conventions of characters, script, and identity positions aligns with Manning's sensitive writing here: that is, to begin from a consideration of the affective environment, made in this case, through music, movement, dimmed lights and low-cost building materials.

Manning takes care in defending her interest in these literatures, arguing that she does not wish to suggest that autism is a condition that is easy to live with, nor does she wish to idealise such life experiences. I reproduce the arguments here carefully and because I feel they have much to offer against the tired and predictable ways we tend to think about politics. What brings her to these literatures is an interest in thinking against the image of a self-sufficient, self-directing body: a body that 'can consciously make decision based on a strong sense of where the body ends and the world begins' (2016: 112). In this way, it ties to longstanding attempts in Geography to posit the body as already in motion: to point out that bodies 'walk, crawl, gesture, run, stumble, reach, fall and embrace' (M cCormack, 2008: 1823), as well as well-established contributions by feminist theorists challenging the presumption of a split between body and mind. Manning's account is interested in the minutiae of bodily experiences, such as a minor gesture 'that often goes by unperceived' (2016: 2). This is close to Noxolo's account of 'place ballet', which she develops from the work of David Seamon (1980). Place ballet focuses on habit or routine, and the minutiae of 
'corporeal decision-making' (2018: 801) at work in the repeated journeys we make across cities through parks or on trains. As Bissell develops further in his work on commuting, such everyday journeys are achieved through a combination of conscious and subconscious processes, involving the micro elements of bodily capacities, lived memories as well as 'forces of enablement and constraint' (2016). This engagement with the micropolitics of barely perceived, or seemingly unchanging movements is powerful for thinking about what took place in this theatre production. Much like Raynor recounts about the possibilities and openings made possible through the repetition of theatre exercises and structured improvisations, the achievements of this performance unfolded at a scale of 'microintensities' (2017: 112). That is to say, 'The Populars' did not weigh into the political directly, by reproducing excerpts of political speeches, of people's 'real' opinions about the vote, or by dramatising two positions in the debate. Rather, it intervened at this register that Manning describes: by addressing questions about how we are affected and moved by others, and by exploring through dance questions of where the body ends and the world begins.

Although the 'Vote Leave' campaign's motto, 'Take Back Control' was never mentioned in this play, the performance challenged the idea of sovereignty as something that can be contained within a body. For example, in the work of inviting the audience to move and play, what arose in this production was the idea that feelings are not contained within bodies but shared between bodies in a space (Brennan, 2004) and can be reworked and reenergised accordingly. Of course, we might describe the experience of attending any piece of theatre as one of sharing feelings with others. What was different in this case was that it 
also invited us to challenge the assumption that 'we are the absolute directors of our movements' (Manning, 2016: 113). Through moving, dancing, laughing, and a shared humility, the performance encouraged ways of being that are not centered around being in control.

Figure 4. 'The Populars', April 2017. Photo courtesy of Volcano Theatre.

Of course we have to be careful with this point: the performance did not seek to celebrate 'lack of control'. Experimental theatre, like all theatre, has to be accompanied by a politics of care (Royal Court Code of Behaviour, 2017), and discussion and input from all members of the cast. But to focus on control as 'lost' is to assume that we already occupy selfsufficient bodies and that vulnerability is something we 'choose' to enter into (Butler, 2016). In contrast, we can read this performance, staged as it was in a disused shop on High Street, as already intertwined with the precarities and violence of everyday life. As Noxolo describes in relation to the Drum in Birmingham, an arts centre that was pivotal for blackled arts in that city for 22 years, the widespread cuts in public funding in the UK make it difficult for any public, innovative, and non-permanent arts institutions to survive (2018). It is for this reason that both Raynor (2017: 110) and Noxolo (2018: 798) stress the importance of the arts in creating spaces for people to come together under conditions of heightened insecurity. Thinking about affect and movement matters politically then because it invites us to take seriously our interdependency as well as to consider how positive affects might be maximised (Figure 4). 
In Judith Butler's account of a form of subjectivity that exceeds ideas about sovereign mastery, she describes the action of 'parking my body in the middle of another's action' as a way of acting that is neither my act or yours but 'something that happens by virtue of the relation between us' (2015: 9). Manning's account strikes a slightly different tone, in that it is less concerned with demonstrably political assemblies than with developing an account of how we are already assembled through sensory encounters, vibrations, and minor movements. As such, Manning gestures towards a reading of politics as something that is less a distinct action and more folded into the work of everyday life. What links Manning and Butler's interventions together, however, is that both show that engaging bodies in movement necessarily means engaging the politics of being with others. In this performance, a focus on tonality, gesture and movement displaced the over-determined categories of autonomous subjects and 'the people' by engaging the affective energies that pass between bodies (Brennan, 2004). The implications of the performance lay with how it interrupted, albeit very modestly, the nationalist affective atmospheres (Closs Stephens, 2016a) circulating through the challenge it presented to the familiar political categories of identities, interests and groups.

In its attention to the affective politics of movement, What this performance did was encourage reflection on the categories, methodologies and standpoints we might rely on in getting to know and understand 'Brexit'. It also opened up other ways of thinking about being with others: through moments of shared laughter, moving together with others, and considering how we are already in motion, undoing the assumption of a static, ahistorical 'people'. As such, the performance avoided amplifying the moods of hostility, suspicion and 
shame by generating other affects and potential lines of connection. In opening up a space to move and to dance, the performance sought to activate 'new modes of perception, inventing languages that speak in the interstices of major tongues' (Manning, 2016: 2). The point here is less about the extent to which this performance was successful in this task- —or how it might be 'rolled out', but in considering how the approach offers insights for the social sciences and humanities in their own engagements with nationalist populism. For example, in engaging 'Brexit' feelings through conversations between families and loved ones, and the tightly held intense feelings that spilled out in spectacular ways following this referendum, the performance avoided presenting characters with views we aready know. Taking a slightly different tact, the performance reflected Manning's engagement with the political as 'what awakens new modes of encounter' (2016: 8). As Bissell argues in another context, 'the micropolitics of [these] barely perceived transitions' are inseparable from the macropolitics of social formations (2016: 399): of ideas about nation, people, representation and population. Overall this engagement with forces of encounter (Gregg and Seigworth, 2010: 2) suggested other ways of understanding and approaching being in common.

Returning to this question of what 'Brexit' felt like, I asked the second year undergraduate students who came to see this play with me on 31 March 2017 to write down how this performance made them feel. Their responses suggest a mixture of emotions, of how the performance gently opened up a space to move, dance and laugh as well as to stay, temporarily, with discomfort:

'happy, curious, nervous'; 
'confused';

'it was kind of fun';

'I was surprised at what we ended up doing';

'excited, stimulated, engaged';

'bad and happy at the same time';

challenged and uncomfortable but gradually more relaxed, laughed, and then joined in';

'quizzical';

'funky, mixed, happy, jazzy, unfit!'

'happy, still grinning, engaged';

[smiley face];

'confused, happy, made me laugh'.

These reports imply that we were all moved by this performance, but not necessarily in ways that were familiar and comforting. What we did, however, was consider how our own bodies, stances, gestures and ways of talking also formed part of these times of heightened political emotions as we experimented just a little with ways of holding ourselves and engaging each other otherwise.

\section{Moving Bodies and Performing the People Anew}

Judith Butler argues that all discursive moves to establish 'the people' are 'in one way or another a bid to have a certain border recognized, whether we understand that as a border 
of a nation or as the frontier of that class of people to be considered 'recognizable' as a people" (Butler, 2015: 5). What is both fascinating and painful in 'Brexit' is watching the sheer determination to arrive at one account of 'the people'. This figure of 'the people', which is central to the system of the nation-state, serves as an originary, yet elusive, symbol of sovereignty (De Genova, 2018). But the people have not only always has been full of contradictions; the people are also in motion. In this article, I have addressed how the affective force of the idea of 'the people' came into view through feelings of shame and resentment in the aftermath of the 'Brexit' vote. Drawing on this performance of 'The Populars', I have also considered how feelings of shame can 'illuminate our intense attachment to the world' (Probyn, 2005: 14) and suggest other ways of feeling and being political. Whilst others have argued that questions of affect and emotion are central understanding the populist politics of the present (M ouffe, 2016), my contribution lies with suggesting that this is not only because populism is scripted through emotions, but because the question of how we engage those affective feelings have implications for the politics of knowledge and how we understand politics more generally. The point is that a politics of affect suggests ways out of a focus on the feelings of different identity groups, which reproduces the categories of populist nationalism. Instead, attuning to minor interventions illuminates what is already shifing in what otherwise seem to be solid and unmoving identity positions.

One dominant way of understanding 'the people' is through the 'principle of separation' that lies at the heart of the colonial project, by affirming a class or identity of one people against another people (M bembe, 2016: 25; Butler 2015). This article has instead engaged 
ideas of the people from the starting point of an urban high street, and through a consideration of the affective force of movement. This represents a political opening, yet there remains much more to do to consider how the idea of 'the people' is nevertheless experienced very differently by various minority populations and especially people of colour. What I have sought to do in this paper is point towards ways out of an oppressive, ahistorical invocation of 'the people' by setting this category in movement. In this invitation to move and to dance, this performance operated on a political register concerned with generating insights about how people gather together and how new forms of being political emerge (Douzinas, 2013). As such, my concern has been less with returning power to the 'proper' people than with generating new stories about what being in Europe might mean, in ways that go beyond the promises and snares of sovereignty. 


\section{References}

Ahluwalia, P and Miller, T (2018) 'Populism -again, seeminly without end', Social Identities, 24 (6): 685-687.

Ahmed, S (2004) The Cultural Politics of Emotion, Edinburgh: Edinburgh UP.

Ahmed, S (2010) The Promise of Happiness, Durham: Duke UP.

Anderson, B and Harrison, P (2010) Taking-Place: Non-Representational Theories and Geography, Farnham, Surrey: Ashgate.

Anderson, B and Holden, A (2008) 'Affective Urbanism and the Event of Hope', Space and Culture, 11(2): 142-159.

Anderson, B and Wilson, H (2017) 'Everyday Brexits', Area, doi: 10.1111/area.12385

Anderson, B (2014) Encountering Affect: Capacities, Apparatuses, Conditions, Fanrham: Ashgate.

Appadurai, A (2005) Fear of Small Numbers, Durham: Duke UP.

Badiou, A (2002) 'Philosophical considerations of the very singular custom of voting: an analysis based on recent ballots in France', Theory \& Event, 6(3). 
Balibar, É (2017) ‘Populism in the American Mirror', 10 January, Retrieved on 19 January 2018. http://www.versobooks.com/blogs/3039-etienne-balibar-populism-in-the-american$\underline{\text { mirror }}$

BBC News, EU Referendum Results, https://www.bbc.com/news/politics/eu_referendum/results (Last visited 12 February 2019).

Bennett, C. (2013) ‘Performing Phenomenology: A practice led investigation of contemporary performance', Unpublished MSc Thesis.

Bennett, C (2017) Interview with Volcano Theatre M ovement Director Catherine Bennett, 28 April.

Bhambra, G (2017) 'Brexit, Trump, and 'methodological whiteness': on the misrecognition of race and class', The British Journal of Sociology, 68 (S1): 214-232.

Bissell, D (2016) ‘Micropolitics and Mobility: Public Transport Commuting and Everyday Encounters with Forces of Enablement and Constraint', Annals of the American Association of Geographers, 106 (2): 394-403.

Brennan, T (2004) The Transmission of Affect, NY: Cornell University Press. 
Butler, J (2015) Notes Toward a Performative Theory of Assembly, Cambridge, Mass: Harvard UP.

Butler, J, Gambetti, Z. and Sabsay, L. (2016) 'Introduction', Vulnerability in Resistance, Durham: Duke UP, 1-11.

Butler, J (2016) 'Rethinking Vulnerability and Resistance', Vulnerability in Resistance, Durham: Duke UP, 12-27.

Cadwalladr, C (2016) 'View from Wales: town showered with cash votes to leave EU', 25 June https://www.theguardian.com/uk-news/2016/jun/25/view-wales-town-showered-eucash-votes-leave-ebbw-vale

Closs Stephens, A (2016a) 'The Affective Atmospheres of Nationalism', Cultural Geographies, 23(2): 181-198.

Closs Stephens, A (2016b) 'National Atmospheres and the 'Brexit' Revolt', Society and Spaxe open site, August 23.

Clough, PT (2010) 'Afterword: The Future of Affect Studies', Body \& Society, 16: 222-230.

Cramer, KJ. (2016) The Politics of Resentment, Chicago and London: Chicago UP. 
Crang, M and Tolia-Kelly, D (2010) 'Nation, Race and Affect: Senses and Sensibilities at National Heritage Sites', EPA: Economy and Space, 42(10): 2315-2331.

Dawney, L (2013) 'The interruption: investigating subjectivation and affect', Environment and Planning D: Society and Space, 31(4), 628-644.

Davies, P (2017) Interview with Paul Davies, director of Volcano Theatre, 7 February.

De Genova, N (2018) 'Rebordering 'the People': Notes on Theorizing Populism', The South Atlantic Quarterly, 117.2: 357-374.

De Genova, N and Tazzioli, M (2016) 'Europe/Crisis: New Keywords on 'the crisis' in and of 'europe', Zone books online, http://nearfuturesonline.org/wpcontent/uploads/2016/01/New-Keywords-Collective_11.pdf.

Dittmer, J and Waterton, E (2017) 'Affecting the body: cultures of militarism at the Australian War Memorial', in Tolia-Kelly, DP, Waterton, E and Watson, S (eds) Heritage, Affect and Emotion, London, NY: Routledge.

Dorling, D. (2016) 'Brexit: the decision of a divided country', BMJ 2016; 354: i3697, doi: http://dx.doi.org/10.1136/bmj.i3697.

Douzinas, C (2013) 'Athens Rising', European Urban and Regional Studies, 20(1): 134-138. 
Edensor, T and Sumartojo, S (2018) 'Geographies of everyday nationhood: experiencing multiculturalism in Melbourne', Nations and Nationalism, 24 (3): 553-578.

Flemmen, $M$ and Savage, M (2017) 'The politics of nationalism and white racism in the UK', The British Journal of Sociology, 68(S1): 233-264.

Fortier, AM (2008) M ulticultural Horizons, London: Routledge.

Fortier, AM (2005) 'Pride Politics and Multiculturalist Citizenship', Ethnic and Racial Studies, 28(3): 559-578.

Goldberg, DT (2002) The Racial State, Oxford: Blackwell.

Goodhart, D (2017) The Road to Somewhere: The Populist Revolt and the Future of Politics, London: Hurst \& Co.

Gregg, M and Seigworth, G (2010) 'An inventory of shimmers', The Affect Theory Reader,Durham: Duke University Press: 1-28.

Hage, G (2000) White Nation: Fantasies of White Supremacy in a M ulticultural Society, NY: Routledge and Pluto Press.

Hochschild, AR (2016) Strangers In Their Own Land, NY: The New Press. 
Hosang, DM and Lowndes, JE (2019) Producers, Parasites, Patriots: Race and the New RightWing Politics of Precarity, University of M innesota Press.

Ingram, A (2011) 'Making geopolitics otherwise: artistic interventions in global political space', The Geographical Journal, 177(3): 218-222.

Johnston, C and Pratt, G (2013) 'Staging Testimony in Nanay', Geographical Review, 103(2): 288-303.

Jones, $\mathrm{R}$ and Merriman, $\mathrm{P}$ (2016) 'Nations, materialities and affects', Progress in Human Geography, 41(5), 600-617.

Land Registry (2018), 'UK House Price Index', http://landregistry.data.gov.uk/app/ukhpi Lentin, A and Titley, G (2011) The Crises of M ulticulturalism: Racism in a Neoliberal Age, London, NY: Zed Books.

Lentin, A (2018) 'Charlie Hebdo: White Context and Black Analytics', Public Culture, 31: 1, $45-67$.

Manning, E (2016) The Minor Gesture, Durham: Duke UP.

Martin, R (1998) Critical M oves: Dance Studies in Theory and Politics, Durham: Duke UP. 
Massey, D (2005) For Space, SAGE.

May T (2016) 'Theresa May's keynote speech at Tory conference in full', The Independent, 5 October.

McCormack, D (2008) 'Geographies for moving bodies: Thinking, Dancing, Spaces', Geography Compass, 2(6): 1822-1836.

McCormack, DP (2013) Refrains for M oving Bodies, Durham: Duke UP.

McKenzie, L (2017) 'The class politics of prejudice: Brexit and the Land of no-hope and glory', The British Journal of Sociology, 68 (S1): 265-280.

Militiz, E., Schurr, C (2016) 'Affective Nationalism: Banalities of belonging in Azerbaijan', Political Geography, 54: 54-63.

Mouffe, C (2018) For a Left Populism, Verso.

Nayak, A (2017) 'Purging the nation: race, conviviality and embodied encouters in the lives of British Bangladeshi Muslim young women', 42(2): 289-302.

Noxolo, P (2018) 'Flat out! Dancing the city at a time of austerity', Environment and Planning D: Society and Space, 36(5), 797-811. 
O’Toole, F (2018) Heroic Failure: Brexit and the Politics of Pain, Apollo.

Orbach, S (2016) 'In therapy, everyone wants to talk about Brexit', The Guardian, 1 July.

Orloff, AS. Ray, R and Savcı, E. (2016) 'Introduction: Perverse Politics? Feminism, AntiImperialism, Multiplicity', Political Power and Social Theory, 30: 1-17.

Painter, J (2008) 'European Citizenship and the Regions', European Urban and Regional Studies, 15(1): 5-19.

Pedwell, C (2013) 'Affect at the Margins: Alternative empapthies in A Small Place', Emotion, Space and Society, 8: 18-26.

Povinelli, EA (2002) The Cunning of Recognition. Indigenous Alterities and the Making of Australian M ulticulturalism, Durham NC: Duke UP.

Probyn, E (2000) 'Sporting Bodies: Dynamics of Shame and Pride', Body \& Society, 6(1): 1328.

Probyn, E (2005) Blush. Faces of Shame, Minnesota UP.

Public Health Wales NHS Trust (2016), 'Measuring Inequalities, Trends in mortality and life expectancy in Aneurin Bevan UHB', http://www.publichealthwalesobservatory.wales.nhs.uk (Last visited 12 Feb 2019). 
Pusca, A (2010), 'Industrial and Human Ruins of Postcommunist Europe', Space and Culture, 13(3): 239-255.

Rao, R (2016) 'Citizens of Nowhere', The Disorder of Things blog, November 28 https://thedisorderofthings.com/2016/11/28/citizens-of-nowhere/ (Last visited 12 Feb 2019).

Ray, R (2017) ‘A case of internal colonialism? Arlie Hochschild's Strangers in their Own Land, British J ournal of Sociology, 68(1): 129-133.

Raynor, R (2017) '(De)composing Habit in Theatre-as-Method', GeoHumanities, 3(1): 108121.

Rogaly, B, Rishbeth, C (2017) 'Sitting outside: Conviviality, self-care and the design of benches in urban public space', Transactions of the Institute of British Geographers, https://doi.org/10.1111/tran.12212

Rogers, A (2017) 'Advancing the Geographies of the Performing Arts: Intercultural aesthetics, migratory mobility and geopolitics', Progress in Human Geography, doi:10.1177/0309132517692056

Royal Court (2017) A Code of Behaviour, https:// d19lfjg8hluhfw.cloudfront.net/wpcontent/uploads/2017/11/06174357/A-Code-of-Behaviour-6Nov.pdf 
Sedgwick, E (2003) Touching Feeling: Affect, Pedagogy, Performativity, Duke UP.

Shilliam, R (2016) 'Racism, multiculturalism and Brexit', Blog entry, 4 July https://robbieshilliam.wordpress.com/2016/07/04/racism-multiculturalism-and-brexit/

Smith, A (2012) 'Indigeneity, Settler Colonialism, White Supremacy', in HoSang, D et al. Racial Formation in the Twenty-First Century, University of California Press: 66-90.

Smith, Z (2016) 'Fences: A Brexit Diary', The New York Review of Books, 18 August.

Stoler, AL (2010) Carnal Knowledge and Imperial Power, Berkeley: University of California Press.

Swansea Profile (2018), https://www.swansea.gov.uk/profiles (Last visited 11 February 2019).

Varoufakis, Y (2017) Adults in the Room: My Battle with Europe's Deep Establishment, Bodley Head.

Welsh Government (2018a) 'European Structural Funds 2014-2020', 2 May https://gov.wales/funding/eu-funds/2014-2020/?lang=en Last visited 5 June. 
West, K (2016), 'How art restarted the heart of Swansea's High Street', The Observer, 8 October https://www.theguardian.com/business/2016/oct/08/art-restarts-heart-swanseahigh-street

Yougov (2016), 'Britain's Youth Voted Remain', https://www.politico.eu/article/britainsyouth-voted-remain-leave-eu-brexit-referendum-stats/

Younge, G (2016) 'Brexit: a disaster decades in the making', The Guardian, 30 June, https://www.theguardian.com/politics/2016/jun/30/brexit-disaster-decades-in-the-making 


\section{Correspondence information:}

Department of Geography,

Singleton Park,

Swansea University

Swansea SA2 8PP

a.c.stephens@swansea.ac.uk

ANGHARAD CLOSS STEPHENS is a Senior Lecturer in the Department of Geography at Swansea University, Swansea, Wales UK SA2 8PP. E-mail:

a.c.stephens@swansea.ac.uk. She is the author of The Persistence of Nationalism: from imagined communities to urban encounters (Routledge, 2013) and is currently recipient of a Leverhulme Research Fellowship to study the affective politics of nationalism. 